\title{
An International Research Project For The Finance Curriculum
}

\author{
Marilyn B. Misch (E-mail: Marilyn.Misch@pepperdine.edu), Pepperdine University
}

\begin{abstract}
This paper discusses a team-based international research project that was incorporated into an international finance class and that would be appropriate for inclusion in a basic corporate finance class with minor modifications. The project requires students to: track the stock prices and trading volumes of several international companies whose shares are traded on U.S. markets, as well as any news events, national interest rate changes, market indices and exchange rates related to those shares; prepare weekly reports analyzing the weekly data; prepare a final report analyzing the findings for the semester; and, present an oral report to the class. The paper discusses the pedagogical approach used, the procedures required to set up the project, the grading techniques employed, the results of the project, and suggestions for incorporating the project in general corporate finance classes.
\end{abstract}

\section{Introduction}

$f$

or more than 20 years, surveys of finance professionals consistently have identified communication and analytical skills as necessary for new graduates in finance (Demong, Pettit, and Campsey 1979; Grablowsky and Rowell 1980; McWilliams and Pantalene 1994; Collier and Wilson 1994; Lessard and Mattson 1996; Baker and Phillips 2000). In addition, since the mid-1990s, computer skills, such as spreadsheet analysis, and knowledge of international business issues and financial markets have been growing in importance as attributes needed by finance students (McWilliams and Pantalene 1994; Collier and Wilson 1994; Lessard and Mattson 1996; Baker and Phillips 2000).

The project described in this paper seeks to develop the skills and attributes identified above by incorporating an international stock-tracking research project into the finance curriculum. The project requires students to: track the U.S. and home-country stock prices and trading volumes of non-U.S. companies with shares traded in the United States and compute the U.S. dollar equivalent prices of foreign market quotations; track market indices and currency data for the countries involved in the study; identify interest rate changes, corporate disclosures, and other news events related to the companies and countries involved in the study and analyze the impact of those items on the trading of the securities; identify disequilibria situations in pricing among markets and evaluate the potential ability of investors to profit from those disequilibria; and, analyze differences in trading volume among markets and suggest potential reasons for the differences.

The project was used in a core international finance course required of all international business and finance majors at a small private liberal-arts university that emphasizes writing throughout the curriculum. For most of the 19 students, the class was their second course in finance, with their first course being a basic corporate finance class.

Readers with comments or questions are encouraged to contact the author via email. 


\section{Project Overview}

This section describes the goals for the project, the procedures undertaken to set up the project, the project requirements and data source information, the introductory material discussed with the students, the data availability and technical issues encountered, and the grading techniques employed.

\section{Project Goals}

In keeping with the desire to develop students' capabilities in the key areas identified above, the primary goals of the project were: 1) to develop students' abilities to obtain and analyze financial information; 2) to develop students' abilities to organize and summarize information and to report that information clearly and concisely; 3 ) to develop students' abilities to present information orally and to defend positions taken; 4) to develop students' understanding of the impact of macroeconomic events and corporate disclosures on stock prices and trading volumes; 5) to develop students' understanding of the concept of market efficiency; and 6) to develop students' understanding of the importance of financial information and the impact of such information on investors.

\section{Project Set-Up Procedures}

Prior to the semester, the instructor obtained lists of non-U.S. registrants traded on NASDAQ and the New York Stock Exchange from the two websites and identified countries with at least 15 registrants. Next, market capitalizations were obtained for the remaining companies from a file available on the NASDAQ website, and the country list was reduced to countries with 15 or more registrants having market capitalizations of at least 100 million U.S. dollars. ${ }^{1}$ Finally, the SIC codes of the remaining companies were obtained from the Securities and Exchange Commission website, and the population was once again reduced to countries having at least 15 registrants with market capitalizations over 100 million U.S. dollars and SIC codes from 2300 to 8700 . $^{2}$ Since Europe was the only region with at least four countries that met the criteria, it was decided to limit the project to European and Canadian companies so that broad North American/European contrasts could be made in addition to U.S./specific country contrasts. It is anticipated that by 2004 there will be a sufficient number of registrants from South America and/or Asia to allow the study to be conducted for these regions as well. To balance roughly the number of companies analyzed by each group, all companies meeting the criteria from France, Germany, and the Netherlands were included in the project, and random samples of companies from Canada and the United Kingdom were included.

Early in the semester, the instructor organized students into groups of three or four people, with each group responsible for analyzing the information for one country. A drawing was held to determine which country each group would analyze. Groups were balanced based on major (finance, international business, or other), overall grade point average, country of origin, and gender. (Although students were not allowed to choose group members as a whole, prior to group selection students were permitted to indicate whether there was a person with whom they did not wish to work. No student indicated a negative preference.)

\section{Project Requirements and Data Source Information}

Once the groups were formed, the requirements for the project were discussed [Appendix 1] and the students were provided both hard copy and electronic versions of the initial spreadsheet listing all companies included in the study [Appendix 2].

After handing out the assignment sheet, the professor briefly commented on five online sources for international financial data and news: the LexisNexis® website for financial reports and industry information; the Federal Reserve Bank of New York website for currency data; the NASDAQ website for U.S. and international stock exchange quotations; the Bank of New York website (adrbny.com) for American Depositary Receipt (ADR) ratios and

\footnotetext{
${ }^{1}$ The market capitalization restriction was employed to focus the research on large companies that are of most interest in studies of foreign registrants.

${ }^{2}$ The SIC restriction was employed to avoid inundating students with natural resource companies and professional service providers.
} 
other ADR information ${ }^{3}$; and the Financial Times website for international financial news. The students were directed to the Federal Reserve Bank of New York website for currency data so that all students would obtain currency information (the noon-buying rate, which is the rate typically used by companies for convenience translations) from the same source. Students at the university were somewhat familiar already with the LexisNexis ${ }^{\circledR}$ website from their work in prior classes, but most students had not explored the other four websites before. In addition to these websites, most students subscribed to The Wall Street Journal, and many subscribed to The Economist magazine.

\section{Introductory Material Discussed with Students}

After discussing data sources, the professor introduced the instruments (ordinary shares, ADRs, NYSE Global Shares $\AA$, and nonvoting foreign shares) foreign registrants typically employ when having shares traded in the United States, as described below.

Most Canadian companies have their ordinary shares traded in the United States in the same manner as U.S. companies, and markets in the two countries are open at approximately the same time; thus, the securities generally should be in equilibrium between markets after considering exchange rates and transaction cost differentials.

Most non-Canadian foreign registrants in the U.S. use American Depositary Receipts (ADRs) when having their shares traded in the United States. ADRs are derivative securities issued by a U.S. bank that holds the company's underlying shares in custody. ADRs generally pay dividends in U.S. dollars and often represent a multiple of a company's underlying domestic shares; therefore, students need to be alert to ADR ratios when analyzing stock data to ensure that prices and trading volume comparisons are being made on an equivalent-share basis. Because the custodian bank owns the underlying shares, the bank has voting rights, but the ADR purchasers do not. Both the differences in dividend payout practices and the lack of voting rights might result in pricing differentials.

Some foreign registrants (particularly German companies) issue NYSE Global Shares ${ }^{\circledR}$, which are ordinary shares that are traded in multiple markets in the same form, with the same rights, but in each market's local currency (New York Stock Exchange website). Since these shares are essentially equivalent from one market to the next, the pricing of global shares should be in equilibrium between markets after considering exchange rates.

Many European companies have corporate structures that concentrate governance in a coalition of managers, major creditors, and/or labor representatives. In order to preserve this structure, to insulate the companies from takeover concerns, to maintain home-country control and to encourage sensitivity to domestic labor and other issues, these companies often use nonvoting stock when entering a second national market through an issuance not involving ADR or global shares. The use of such nonvoting shares might result in pricing differences compared to ordinary shares if the voting rights are perceived as valuable.

\section{Data availability and Technical Issues}

The project was originally slated to begin in the third week of class, but because the project was conducted during the fall 2001 semester, class did not meet on September $11^{\text {th }}$, and there was a short period when U.S. markets were closed following the attacks on the World Trade Center and the Pentagon; thus, the project was postponed for one week. When the U.S. markets reopened, students found that prices in the U.S. generally were in equilibrium with international prices, and that the U.S. and international markets were closely correlated for the first few days.

Early in the semester, students from four of the five groups came to the professor asking for help finding stock quotations that could not be located using one of the online archives or The Wall Street Journal. If the professor verified that the quotations were not available from these sources, the students generally were permitted to note in their reports the lack of data availability for those companies and to exclude such companies from the remainder of the research. The one exception to this rule was made for Dutch companies, five of which were not traded in

\footnotetext{
${ }^{3}$ Currently, the NYSE website at www.NYSE.com/international/international.html (Non-U.S. Listed Companies) also has a listing of ADR ratios for NYSE companies.
} 
Amsterdam. The students in the Netherlands group were asked to continue tracking these securities in the U.S., even though Amsterdam exchange quotations did not exist. Of the companies originally included in the project, data could not be located for two of the Canadian, three of the French, none of the German, four of the Dutch, and two of the British firms. In addition, one of the Canadian companies was acquired in September, and ceased to be available for tracking.

\section{Grading}

The grading for the projects was broken into three parts - 45 points were devoted to the weekly reports, 75 points were devoted to the final written project and 10 points were devoted to the oral presentation.

The weekly reports were graded on a 10-point scale, using the following rubric:

- 10 points: The spreadsheet is complete and accurate. The report is well written and free of grammatical and mechanical errors. The report addresses each of the required topics, focuses on important issues and demonstrates an understanding of the relationship between macroeconomic events, corporate disclosures, and the market performance of securities.

- 9 points: The spreadsheet is complete and accurate. The report is well written, but may have one or two minor grammatical or mechanical errors. The report addresses the required topics and focuses on important issues, but may not synthesize the material being discussed.

- 8 points: The spreadsheet is complete but may have one minor error, such as a transposition of a security price. The report is free of major grammatical or mechanical errors, but lacks organization. The report includes a discussion of trends in the performance of the U.S. and home-country markets, but lacks a discussion of the correlation between the two markets. The report contains a listing of changes that have occurred during the week, but does not differentiate between important and unimportant issues.

- 7 points: The spreadsheet is missing data for one company due to a team error. The report is free of major grammatical or mechanical errors, but lacks organization. The report contains a listing of changes that have occurred during the week, but does not discuss trends or differentiate between important and unimportant issues. The report may omit discussion of a major news event or change.

- 0 points: The spreadsheet is inaccurate and/or missing data for more than one company due to team error. The report contains major grammatical or mechanical errors. The report fails to include a discussion of market trends. The report lists some of the changes that have occurred during the week, but does not demonstrate an understanding of the relationship between the events that have occurred and the performance of the securities and markets.

At the end of the term, the lowest score was dropped and the remaining scores averaged, then the percentage average was multiplied by 45 to determine the overall weekly report grade. To verify the accuracy of the raw spreadsheet data, the professor arbitrarily chose one company from each country twice per week and recorded the price and trading volume in each market as reported on the NASDAQ website. Then, when the reports came in, the professor verified that the data included on the spreadsheet was accurate. This method of spot-checking the spreadsheet data required only 15 minutes twice each week.

The final projects were graded in two phases:

- $\quad$ First, the papers were graded for composition on a pass/fail basis. Projects with excessive grammatical and mechanical errors were required to be resubmitted. Any projects that failed this phase had to be corrected and resubmitted within one week of the due date and the written project grade was docked 15 points. ${ }^{4}$

- $\quad$ Second, the papers were reviewed for content and graded using the following rubric:

\footnotetext{
${ }^{4}$ Groups had the option of scheduling meetings with the professor to discuss drafts of their written analyses no less than one week prior to submission of their projects. Each group met with the professor at least once approximately 10 days prior to the due date, although two groups brought incomplete drafts. No group failed the writing phase, although one group's paper was marginal.
} 
* 70-75 points: The paper is well written and free of grammatical and mechanical errors. The report addresses each of the issues specified in the requirements, demonstrates a thorough understanding of the material, and uses appropriate examples and charts to show the relationships among data.

- 64-69 points: The paper is well written but may have minor grammatical and mechanical errors or lack smooth transitions. The report addresses the issues specified in the requirements and demonstrates understanding, but does not fully synthesize the material being discussed or integrate appendix material with the narrative.

- 58-63 points: The paper does not have excessive grammatical or mechanical errors. The report addresses the issues specified in the requirements, but demonstrates only moderate understanding and lacks integration.

* 52-57 points: The paper does not have excessive grammatical or mechanical errors. The report addresses the issues specified in the requirements, but demonstrates only minimal understanding of one or more of the issues.

The oral presentations were graded based on the importance and relevance of the matters discussed the professionalism of the presentation, and the responsiveness to questions. Scores ranged from 7 to 10 points.

\section{Results}

At the beginning of the project, the professor employed a brief survey in class asking students whether they believed that the share prices of cross-listed securities were within $1 \%$ of each other in the U.S. and the home country and whether trading volume was equivalent in the two markets, higher in the U.S. or higher in the home country. At that time, only $50 \%$ of the class expected the markets to be in equilibrium and $75 \%$ of the class expected trading volume to be the same in the two markets or higher in the United States. Contrary to their expectations, the students found that markets generally are in equilibrium, that trading volumes for European shares are higher in the home country, and that a volume pattern for Canadian companies could not be determined. The German group did find persistent price differences of $3 \%$ or more for four securities, however, and noted that this behavior was concentrated in lightly-traded and low-value securities.

For the weekly reports, four of the five groups did a consistently excellent job of completing the spreadsheet accurately, identifying major news events and disclosures, and relating the events and disclosures to the trading behavior of the shares and markets under review and the concepts of market efficiency. For example, groups discussed: 1) the relationship between news regarding the response to the September 11 attacks and the behavior of markets and individual securities, such as KLM shares; 2) the differing share price reactions to disclosures that were expected by the market versus disclosures that were surprises; 3 ) the impact of industry information on trading; and 4) the impact of interest rate changes on exchange rates. One group did not complete the spreadsheet accurately for the first three weeks of the project, having problems with both the pricing data and the percentage change calculations, and the group ignored repeated requests from the professor to meet in order to solve the problem. After the third week (and three zeroes on the weekly reports) the group finally met with the professor and the difficulties with the spreadsheet were resolved, but the group struggled with the analysis of the data for most of the term, generally receiving sevens and eights, rather than nines and tens, on the reports.

For the final projects, the groups performed very well. Each group demonstrated at least moderate understanding with regard to the correlation between markets, the concept of market efficiency, the existence of disequilibria, and the trading pattern among markets; and all of the groups demonstrated thorough understanding of the role of exchange rates in equilibrating prices among markets. Two groups did an outstanding job, overall. These groups demonstrated the ability to analyze the relationship between macroeconomic disclosures, exchange rates, and market performance, to synthesize the data collected, and to summarize the data in graphs and charts that illustrated the relationships identified. For example, groups commented on: the need to consider transaction costs and to compare contemporaneous market and exchange-rate quotations rather than closing market and noon-buying rate quotations to determine whether markets are really out of equilibrium; the relationship between trading volume and pricing differentials; and, the relationship between national economic disclosures, such as trade and productivity figures, and 
the behavior of markets and securities.

Finally, in the university-mandated anonymous teacher evaluations given at the end of class, 12 of the 19 students commented positively on the project, only 1 commented negatively, and 10 of the students noted that the project was the thing that they liked best about the class. Several students noted that the project greatly increased their understanding of the stock market and that it was a much better alternative than a traditional term paper. Overall, the project was viewed as a success by both the students and the professor.

\section{Difficulties Encountered and Suggestions for the Future}

The major difficulty encountered in implementing this project was the lack of availability of data for several of the companies originally included in the testing. The absence of data in the Amsterdam market, in particular, limited the ability of the Netherlands group to analyze pricing behavior, although it did allow the group to comment on the depth and breadth of the Amsterdam exchange. In the future, as cross-listing increases, and more countries have sufficient registrants in the U.S. to permit reasonable sample sizes, this problem should be somewhat mitigated. For the upcoming semester, the professor intends to lower the market capitalization requirement in order to make more companies eligible for the study. Lowering this requirement will also allow comparisons of trading behavior based on company size.

A second difficulty encountered was the poor performance of one group for the first three weeks of the project and the lack of responsiveness to requests for meetings. In the future, the professor intends to make the first weekly report a practice report, and to require each group to schedule a 10-minute meeting with the professor the day the first reports are handed back in order to discuss the group's performance and suggestions for improvement.

A final difficulty, from the professor's standpoint, was the time involved in verifying the citations for the news articles referred to in the weekly reports. In the future, the professor intends to require students to submit copies of the articles along with the one-page reports. This requirement will have the added benefit of creating a file of current articles related to the course.

\section{Suggestions for Implementation in Other Courses}

This paper has described a group-based stock-tracking research project that was incorporated into an international finance course, but the framework given could be adapted easily to other courses seeking to add an international dimension. The only major change required for use in a basic corporate finance course would be a lessened emphasis on the relationship between interest rates and exchange rates. This parity relationship is a major topic in international finance courses, but is not a topic discussed at length in traditional corporate finance classes. The project could be adapted to a money and banking class by focusing on cross-listed banks and financial institutions, by further restricting the SIC codes considered for inclusion in the study. The project could be adapted for individual student use by having each student identify and prepare a report on one or two companies from a single country, such as the United Kingdom, that has many registrants in the U.S., and then having class discussion of the overall results. In such a case, the project could be limited to the weekly reports, if a final paper is not desired. Finally, as the number of foreign registrants in the United States expands, the project could be modified to include Asian, South American, and other regional groupings.

\section{Conclusion}

As world economies and stock markets become more integrated, it becomes increasingly important for business majors to understand global finance. To understand the trading behavior of individual securities, students must understand the interrelationships that exist among national securities' markets, as well as the relationship between macroeconomic events and market behavior. In addition, students must be able to recognize market imperfections and to assess the potential for investors to profit from such imperfections. Research projects such as the one described in this paper can improve students' understanding of international finance, while enhancing students' analytical and communication skills-in the process developing the capabilities that graduates will need to compete 
in the $21^{\text {st }}$ century.

\section{Appendix 1: Team Case Requirements}

\section{Required: Weekly Assignment}

1. Each day obtain: a) the closing U.S. and home country stock prices and trading volumes for each of the companies from your country; b) the closing Dow Jones Industrial Average; c) the closing S\&P 500 average; d) the closing market average for your country; and e) the noon-buying exchange rate between the U.S. dollar and your country's currency.

2. Using the data obtained in (1), complete the template that you have been given. If you cannot obtain data for one of your companies, include a footnote stating the reason for the lack of data availability.

3. Obtain copies of any articles related to your companies and to U.S. and home country interest rates.

4. Using the data compiled in (2) and the articles obtained in (3), prepare a one-to-two page paper discussing a) any trends in the U.S. and home country markets for the week; b) any issues that appear to have affected your companies, markets, and exchange rates during the week; and c) any substantial changes in the performance of your companies during the week, with regard to pricing or volume.

Note:

1. Your spreadsheets and written analyses must be submitted electronically by 9:00 a.m. each Tuesday morning and you must bring hard copies to class with you. We will discuss the results at the beginning of class and a representative from each team will be expected to brief the class on his or her team's findings for the week.

2. Your written analysis must be typed, double-spaced, and have at least a 10-point font.

\section{Required: Final Project}

1. Using the data obtained during the semester: a) discuss the correlation between the U.S. and home-country markets; b) analyze the impact of interest rate changes, exchange rate changes, corporate disclosures, and other news events related to the companies and countries involved in the study on the trading of your companies' securities in both the U.S. and the home-country markets; c) identify disequilibria situations in pricing among markets and evaluate the potential ability of investors to profit from those disequilibria; and, d) discuss any patterns and differences among markets in trading volume with regard to your companies' securities and suggest potential reasons for the differences.

Note:

1. Your written analysis is limited to 10 (ten) pages not including appendices, and must be typed, doublespaced, and have at least a 10-point font. You must submit a hard copy of the completed EXCEL spreadsheet along with your final report.

2. The assignment is due on the date specified in the syllabus. You must turn in your notebook in class and email the EXCEL spreadsheet to me as an attachment.

Required: Team Presentation 
1. Prepare a 15 minute presentation for the class summarizing the results of your team's project. Each member of the team MUST participate in the presentation, and after the presentation you will be expected to entertain questions for 5-10 minutes from both the class and the professor.

\section{References}

1. Baker, H. Kent and Aaron L. Phillips, 2000, "Knowledge, Skills, and Attributes Needed to Succeed in Financial Management: Evidence from Entry-Level and Mid-Level Practitioners," Financial Practice \& Education 10:2 (Fall/Winter), 189-200.

2. Bank of New York, 2001, "Depositary Receipts," http://www.adrbny.com.

3. Collier, Ben and Michael J. Wilson, 1994, "What Does a Graduate Need? Evidence from the Careers and Opinions of CFOs," Financial Practice \& Education 4:2 (Fall/Winter), 59-65.

4. DeMong, Richard F., Laurence C. Pettit and B.J. Campsey, 1979, "Finance Curriculum for the Future: Perceptions of Practitioners versus Academicians," Journal of Financial Education 8 (Fall), 45-48.

5. Federal Reserve Bank of New York, 2001, "Noon Buying Rate Directory," ftp://ftp.ny.frb.org/ forex/12noon.

6. Grablowsky, B.J. and D.R. Rowell, 1980, “The Market for Finance Majors: The Myths and Realities Reconsidered," Journal of Financial Education 9 (Fall), 33-41.

7. Lessard, Jeffrey P. and Kyle L. Mattson, 1996, "An Empirical Evaluation of Intergroup Issues on Curricular Issues in Finance," Journal of Financial Education 22:1 (spring), 47-55.

8. LexisNexis ${ }^{\circledR}, 2001$, "Business/Company Information," http://web.lexis-nexis.com/universe.

9. McWilliams, Victoria B. and Coleen C. Pantalene, 1994, "Structuring the Finance Curriculum: A Survey," Financial Practice \& Education 4:1 (Spring/Summer), 37-46.

10. NASDAQ, 2001, "Global Markets Quotes," http://www.international.nasdaq.com/asp/globalMarkets.asp.

11. NASDAQ, 2001, "Non-U.S. NASDAQ Company list," http://www.nasdaq.com/about/ NonUSoutput_AO.stm. This website is no longer active; the new website is http://www.quotes.nasdaq.com.

12. New York Stock Exchange, 2001a, "Complete List of Non-U.S. Companies-2001," http: //www.nyse.com/ international/international.html. (Information and Resources: NYSE Global Shares®).

13. New York Stock Exchange, 2001b, "Global Shares," http: //www.nyse.com/international/ international.html. (Information and Resources: NYSE Global Shares®).

14. U.S. Securities and Exchange Commission, 2001, "EDGAR Company Search" function, http://www.sec.gov/edgar/ searchedgar/companysearch.html. 


\section{APPENDIX 2}

\begin{tabular}{|c|c|c|c|c|c|c|c|c|c|c|c|c|c|c|c|c|c|c|c|c|c|c|c|}
\hline COMPANY & CTRY & MARKET & ADR? & RATIO & SIC & \begin{tabular}{|c|} 
US \\
SYMBOL
\end{tabular} & \begin{tabular}{|l|} 
FOREIGN \\
SYMBOL
\end{tabular} & DATE & \begin{tabular}{|l|} 
MKT CAP \\
USD (MIL) \\
\end{tabular} & $\begin{array}{c}\text { US VOL } \\
(000 \text { s) }\end{array}$ & $\begin{array}{c}\begin{array}{c}\text { FOR VOL } \\
(000 s)\end{array} \\
\end{array}$ & \begin{tabular}{|c|} 
US \\
PRICE
\end{tabular} & \begin{tabular}{|c|} 
USD \\
EQUIV
\end{tabular} & \begin{tabular}{|c|} 
FOR \\
PRICE \\
\end{tabular} & \begin{tabular}{|l|} 
EXCH \\
RATE \\
\end{tabular} & \begin{tabular}{|c|} 
US \\
$\% \Delta$
\end{tabular} & \begin{tabular}{|l|} 
FOR \\
$\% \Delta \Delta$ \\
\end{tabular} & DJIA & $\begin{array}{l}\text { DIIA } \\
\% \Delta\end{array}$ & S\&P 500 & $\mid \begin{array}{c}\text { S\&P 500 } \\
\% \Delta \Delta\end{array}$ & \begin{tabular}{|c|} 
FOR \\
INDEX \\
\end{tabular} & \begin{tabular}{|c|} 
FOR IND \\
$\% \Delta$
\end{tabular} \\
\hline & & & & & & & & & & & & & & & & & & & & & & & \\
\hline ABITIBI CONSOLIDATED INC & Can & NYSE & & & 2621 & $\mathrm{ABY}$ & & & & & & & & & & & & & & & & & \\
\hline A T\&T Canada, Inc. & Can & NASDAQ & & & 4813 & ATTC & & & & & & & & & & & & & & & & & \\
\hline Bell Canada International, Inc. & Can & NASDAQ & & & 4813 & BCICF & & & & & & & & & & & & & & & & & \\
\hline Biomira Inc. & Can & NASDAQ & & & 2835 & BIOM & & & & & & & & & & & & & & & & & \\
\hline BROOKFIELD PROPERTIES COR & Can & NYSE & & & 6512 & BPO & & & & & & & & & & & & & & & & & \\
\hline Cognos Incorporated & Can & NASDAQ & & & 7372 & COGN & & & & & & & & & & & & & & & & & \\
\hline Cryptologic, Inc. & Can & NASDAQ & & & 7389 & CRYP & & & & & & & & & & & & & & & & & \\
\hline Descartes Systems Group Inc. (The) & Can & NASDAQ & & & 7372 & DSGX & & & & & & & & & & & & & & & & & \\
\hline Enbridge Inc. & Can & NASDAQ & & & 4610 & ENBR & & & & & & & & & & & & & & & & & \\
\hline Genesis Microchip Inc. & Can & NASDAQ & & & 3674 & GNSS & & & & & & & & & & & & & & & & & \\
\hline GT Group Telecom, Inc. & Can & NASDAQ & & & 4813 & GTTLB & & & & & & & & & & & & & & & & & \\
\hline KINGSW A Y FINANCIAL SVCS I & Can & NYSE & & & 6331 & KFS & & & & & & & & & & & & & & & & & \\
\hline Methanex Corporation & Can & NASDAQ & & & 2860 & $\mathrm{MEOH}$ & & & & & & & & & & & & & & & & & \\
\hline MFC Bancorp Ltd. & Can & NASDAQ & & & 6211 & MXBIF & & & & & & & & & & & & & & & & & \\
\hline Nortel Networks Corp & Can & NYSE & & & 3661 & NT & & & & & & & & & & & & & & & & & \\
\hline Open Text Corporation & Can & NASDAQ & & & 7373 & OTEX & & & & & & & & & & & & & & & & & \\
\hline ALLIANCE FOREST PRODS INC & Can & NYSE & & & 2621 & PFA & & & & & & & & & & & & & & & & & \\
\hline Research in Motion Limited & Can & NASDAQ & & & 3661 & RIMM & & & & & & & & & & & & & & & & & \\
\hline SUN LIFE FINANCIAL & Can & NYSE & & & 6770 & SLC & & & & & & & & & & & & & & & & & \\
\hline Tesco Corporation & Can & NASDAQ & & & 3533 & TESOF & & & & & & & & & & & & & & & & & \\
\hline TRIZEC HAHN CORP & Can & NYSE & & & 6500 & TZH & & & & & & & & & & & & & & & & & \\
\hline Zi Corporation & Can & NASDAQ & & & 7372 & ZICA & & & & & & & & & & & & & & & & & \\
\hline GROUPE AB S A & Fr & NYSE & ADR & & 4833 & ABG & & & & & & & & & & & & & & & & & \\
\hline ActivCard S.A. & Fr & NASDAQ & ADR & & 7372 & ACTI & & & & & & & & & & & & & & & & & \\
\hline ALCATEL & $\mathrm{Fr}$ & NYSE & ADR & & 3661 & ALA & & & & & & & & & & & & & & & & & \\
\hline Alcatel & $\mathrm{Fr}$ & NASDAQ & & & 3661 & ALAO & & & & & & & & & & & & & & & & & \\
\hline ALSTOM SA & $\mathrm{Fr}$ & NYSE & ADR & & 3562 & ALS & & & & & & & & & & & & & & & & & \\
\hline A VENTIS & $\mathrm{Fr}$ & NYSE & ADR & & 2800 & AVE & & & & & & & & & & & & & & & & & \\
\hline AXA & $\mathrm{Fr}$ & NYSE & ADR & & 6311 & AXA & & & & & & & & & & & & & & & & & \\
\hline Business Objects S.A. & $\mathrm{Fr}$ & NASDAQ & ADR & & 7372 & BOBJ & & & & & & & & & & & & & & & & & \\
\hline Coflexip & Fr & $\begin{array}{l}\text { NASDAQ } \\
\text { NASDAQ }\end{array}$ & $\begin{array}{l}\text { ADR } \\
\text { ADR }\end{array}$ & & 3317 & CXIPY & & & & & & & & & & & & & & & & & \\
\hline Dassault Systemes, S.A. & $\mathrm{Fr}$ & NASDAQ & ADR & & 7372 & DASTY & & & & & & & & & & & & & & & & & \\
\hline FRANCE TELECOM & $\mathrm{Fr}$ & NYSE & ADR & & 4813 & FTE & & & & & & & & & & & & & & & & & \\
\hline Havas Advertising & Fr & NASDAQ & ADR & & 7311 & HADV & & & & & & & & & & & & & & & & & \\
\hline $\begin{array}{l}\text { Ilog S.A. } \\
\text { Inting }\end{array}$ & $\mathrm{Fr}$ & NASDAQ & ADR & & 7372 & ILOG & & & & & & & & & & & & & & & & & \\
\hline LVMH & $\mathrm{Fr}$ & NASDAQ & ADR & & 2340 & LVMHY & & & & & & & & & & & & & & & & & \\
\hline PECHINEY & $\mathrm{Fr}$ & NYSE & ADR & & 3411 & PY & & & & & & & & & & & & & & & & & \\
\hline RHODIA & $\mathrm{Fr}$ & NYSE & ADR & & 2800 & RHA & & & & & & & & & & & & & & & & & \\
\hline SCOR & $\mathrm{Fr}$ & NYSE & ADR & & 6311 & $\mathrm{SCO}$ & & & & & & & & & & & & & & & & & \\
\hline STMicroelectronics NV & $\mathrm{Fr}$ & NYSE & & & 3674 & STM & & & & & & & & & & & & & & & & & \\
\hline THOMSON MULTIMEDIA & $\mathrm{Fr}$ & NYSE & ADR & & 3651 & TMS & & & & & & & & & & & & & & & & & \\
\hline Total Fina Elf S.A. & $\mathrm{Fr}$ & NYSE & ADR & & 2911 & TOT & & & & & & & & & & & & & & & & & \\
\hline Vivendi Universal & $\mathrm{Fr}$ & NYSE & ADR & & 7389 & $\mathrm{v}$ & & & & & & & & & & & & & & & & & \\
\hline Wavecom S.A. & $\mathrm{Fr}$ & NASDAQ & ADR & & 3663 & WVCM & & & & & & & & & & & & & & & & & \\
\hline CELANESE AG & Ger & NYSE & GS & & 2673 & $\mathrm{CZ}$ & & & & & & & & & & & & & & & & & \\
\hline DAIMLERCHRYSLER AG & Ger & NYSE & GS & & 3711 & $\mathrm{DCX}$ & & & & & & & & & & & & & & & & & \\
\hline DEUTSCHE TELEKOM AG ADS & Ger & NYSE & ADR & & 4813 & DT & & & & & & & & & & & & & & & & & \\
\hline EON AG & Ger & NYSE & ADR & & 4731 & EON & & & & & & & & & & & & & & & & & \\
\hline EPCOS AG & Ger & NYSE & ADR & & 3670 & EPC & & & & & & & & & & & & & & & & & \\
\hline FRESENIUS MEDICAL CARE AG & Ger & NYSE & ADR & & 3841 & FMS & & & & & & & & & & & & & & & & & \\
\hline INFINEON TECHNOLOGIES AG & Ger & NYSE & ADR & & 3674 & IFX & & & & & & & & & & & & & & & & & \\
\hline INTERSHOP Communications AG & Ger & NASDAQ & ADR & & 7373 & ISHP & & & & & & & & & & & & & & & & & \\
\hline PFEIFFER VACUUM TECH A G & Ger & NYSE & ADR & & 3564 & & & & & & & & & & & & & & & & & & \\
\hline QS Communications AG & Ger & NASDAQ & ADR & & 4813 & QSCG & & & & & & & & & & & & & & & & & \\
\hline SAPAG & Ger & NYSE & ADR & & 7372 & SAP & & & & & & & & & & & & & & & & & \\
\hline S GLCARBON AG & Ger & NYSE & ADR & & 3620 & SGG & & & & & & & & & & & & & & & & & \\
\hline SCHERING AG & Ger & NYSE & ADR & & 2834 & SHR & & & & & & & & & & & & & & & & & \\
\hline SIEMENS A G & Ger & NYSE & ADR & & 4899 & SI & & & & & & & & & & & & & & & & & \\
\hline iXOS Software AG & Ger & NASDAQ & ADR & & 7372 & XOSY & & & & & & & & & & & & & & & & & \\
\hline
\end{tabular}




\section{APPENDIX 2}

\begin{tabular}{|c|c|c|c|c|c|c|c|c|c|c|c|c|c|c|c|c|c|c|c|c|c|c|c|}
\hline COMPANY & CTRY & MARKET & ADR? & RATIO & SIC & \begin{tabular}{|c|} 
US \\
SYMBOL
\end{tabular} & \begin{tabular}{|l|} 
FOREIGN \\
SYMBOL
\end{tabular} & DATE & \begin{tabular}{|l|} 
MKT CAP \\
USD (MIL) \\
\end{tabular} & \begin{tabular}{|c|} 
US VOL \\
$(000 \mathrm{~s})$
\end{tabular} & \begin{tabular}{|c|}
$\begin{array}{c}\text { FOR VOL } \\
(000 s)\end{array}$ \\
\end{tabular} & \begin{tabular}{|c|} 
US \\
PRICE \\
\end{tabular} & \begin{tabular}{|c|} 
USD \\
EQUIV \\
\end{tabular} & \begin{tabular}{|c|} 
FOR \\
PRICE \\
\end{tabular} & \begin{tabular}{|l} 
EXCH \\
RATE \\
\end{tabular} & \begin{tabular}{|l|} 
US \\
$\% \Delta$ \\
\end{tabular} & $\begin{array}{l}\text { FOR } \\
\% \Delta \Delta \\
\end{array}$ & DJIA & $\begin{array}{l}\text { DIIA } \\
\% \Delta \\
\end{array}$ & S\&P 500 & $\begin{array}{c}\text { S\&P 500 } \\
\% \Delta \Delta\end{array}$ & \begin{tabular}{|c|} 
FOR \\
INDEX \\
\end{tabular} & \begin{tabular}{|c} 
FOR IND \\
$\% \Delta$
\end{tabular} \\
\hline & & & & & & & & & & & & & & & & & & & & & & & \\
\hline A B N AMRO HLDGS N V & Neth & NYSE & & & 6099 & ABN & & & & & & & & & & & & & & & & & \\
\hline AEGON NV & Neth & NYSE & & & 6311 & AEG & & & & & & & & & & & & & & & & & \\
\hline Akzo Nobel N.V. & Neth & NASDAQ & ADR & & 2800 & AKZOY & & & & & & & & & & & & & & & & & \\
\hline ASM International N.V. & Neth & NASDAQ & & & 3559 & ASMI & & & & & & & & & & & & & & & & & \\
\hline ASML Holding N.V. & Neth & NASDAQ & & & 3559 & ASML & & & & & & & & & & & & & & & & & \\
\hline BE Semiconductor Industries NV & Neth & NASDAQ & & & 3674 & BESI & & & & & & & & & & & & & & & & & \\
\hline CompleTel Europe N.V. & Neth & NASDAQ & & & 4813 & CLTL & & & & & & & & & & & & & & & & & \\
\hline CNH GLOBAL NV & Neth & NYSE & & & 5045 & $\mathrm{CNH}$ & & & & & & & & & & & & & & & & & \\
\hline ELSEVIER N V & Neth & NYSE & ADR & & 2741 & ENL & & & & & & & & & & & & & & & & & \\
\hline EQUANT INC & Neth & NYSE & & & 7380 & ENT & & & & & & & & & & & & & & & & & \\
\hline GUCCI GROUP N V & Neth & NYSE & & & 3100 & GUC & & & & & & & & & & & & & & & & & \\
\hline Indigo N.V. & Neth & NASDAQ & & & 3555 & INDG & & & & & & & & & & & & & & & & & \\
\hline ISPAT INTL N V & Neth & NYSE & & & 3312 & IST & & & & & & & & & & & & & & & & & \\
\hline K L M ROYAL DUTCH AIRL & Neth & NYSE & & & 4512 & KLM & & & & & & & & & & & & & & & & & \\
\hline Royal KPN NV & Neth & NYSE & ADR & & 4813 & KPN & & & & & & & & & & & & & & & & & \\
\hline Metron Technology N.V. & Neth & NASDAQ & & & 3559 & MTCH & & & & & & & & & & & & & & & & & \\
\hline Oce NV & Neth & NASDAQ & ADR & & 3861 & OCENY & & & & & & & & & & & & & & & & & \\
\hline Orthofix International N.V. & Neth & NASDAQ & & & 3841 & OFIX & & & & & & & & & & & & & & & & & \\
\hline Koninklijke Philips Elect & Neth & NYSE & & & 3600 & PHG & & & & & & & & & & & & & & & & & \\
\hline Qiagen N.V. & Neth & NASDAQ & & & 2836 & QGENF & & & & & & & & & & & & & & & & & \\
\hline Royal Dutch Petroleum & Neth & NYSE & & & 2911 & $\mathrm{RD}$ & & & & & & & & & & & & & & & & & \\
\hline Trader.com N.V. & Neth & NASDAQ & & & 2721 & TRDR & & & & & & & & & & & & & & & & & \\
\hline United Pan-Europe Comm. N.V. & Neth & NASDAQ & ADR & & 4841 & UPCOY & & & & & & & & & & & & & & & & & \\
\hline Velcro Industries N.V. & Neth & NASDAQ & & & 3965 & VELCF & & & & & & & & & & & & & & & & & \\
\hline ARM Holdings, plc & U.K. & NASDAQ & ADR & & 3674 & ARMHY & & & & & & & & & & & & & & & & & \\
\hline AMVESCAP P LC & U.K. & NYSE & ADR & & 6282 & AVZ & & & & & & & & & & & & & & & & & \\
\hline ASTRAZENECA PLC & U.K. & NYSE & ADR & & 2834 & AZN & & & & & & & & & & & & & & & & & \\
\hline Baltimore Technologies plc & U.K. & NASDAQ & ADR & & 7372 & BALT & & & & & & & & & & & & & & & & & \\
\hline British Biotech plc & U.K. & NASDAQ & ADR & & 2834 & BBIOY & & & & & & & & & & & & & & & & & \\
\hline BARCLAYS P LC & U.K. & NYSE & ADR & & 6029 & BCS & & & & & & & & & & & & & & & & & \\
\hline BP PLC & U.K. & NYSE & ADR & & 2911 & BP & & & & & & & & & & & & & & & & & \\
\hline BRITISH TELECOMM P LC & U.K. & NYSE & ADR & & 4813 & BTY & & & & & & & & & & & & & & & & & \\
\hline CABLE \& WIRELESS P LC & U.K. & NYSE & ADR & & 4813 & CWP & & & & & & & & & & & & & & & & & \\
\hline Eidos plc & U.K. & NASDAQ & ADR & & 7372 & EIDSY & & & & & & & & & & & & & & & & & \\
\hline Marconi plc & U.K. & NASDAQ & ADR & & 3661 & MONI & & & & & & & & & & & & & & & & & \\
\hline NDS Group plc. & U.K. & NASDAQ & ADR & & 7372 & NNDS & & & & & & & & & & & & & & & & & \\
\hline POWERGEN P LC & U.K. & NYSE & ADR & & 4911 & PWG & & & & & & & & & & & & & & & & & \\
\hline Rexam, Plc & U.K. & NASDAQ & ADR & & 2650 & REXMY & & & & & & & & & & & & & & & & & \\
\hline REED INTL P LC & U.K. & NYSE & ADR & & 2741 & RUK & & & & & & & & & & & & & & & & & \\
\hline Shire Pharmaceuticals Group, plc & U.K. & NASDAQ & ADR & & 2834 & SHPGY & & & & & & & & & & & & & & & & & \\
\hline SMITH AND NEPHEW PLC & U.K. & NYSE & ADR & & 3842 & SNN & & & & & & & & & & & & & & & & & \\
\hline SCOTTISH POWER P LC & U.K. & NYSE & ADR & & 4900 & SPI & & & & & & & & & & & & & & & & & \\
\hline Stolt-Nielsen S.A. & U.K. & NASDAQ & ADR & & 4412 & SNSA & & & & & & & & & & & & & & & & & \\
\hline Telewest Communications plc & U.K. & NASDAQ & ADR & & 4841 & TWSTY & & & & & & & & & & & & & & & & & \\
\hline United Business Media plc & U.K. & NASDAQ & ADR & & 2711 & UNEWY & & & & & & & & & & & & & & & & & \\
\hline UNITED UTILITIES P L C & U.K. & NYSE & ADR & & 4931 & UU & & & & & & & & & & & & & & & & & \\
\hline
\end{tabular}


Notes 